DE DE GRUYTER OPEN
Research Article

(C) 2017 Victor Imanuel W. Nalle. This is an open access article licensed under the Creative Commons Attribution-NonCommercial-NoDerivs License (http://creativecommons.org/licenses/by-nc-nd/3.0/).

\title{
Blasphemy Law and Public Neutrality in Indonesia
}

\author{
Victor Imanuel W. Nalle
}

Faculty of Law, Darma Cendika Catholic University, Indonesia

\section{Doi:10.5901/mjss.2017.v8n2p57}

\begin{abstract}
Indonesia has the potential for social conflict and violence due to blasphemy. Currently, Indonesia has a blasphemy law that has been in effect since 1965. The blasphemy law formed on political factors and tend to ignore the public neutrality. Recently due to a case of blasphemy by the Governor of Jakarta, relevance of blasphemy law be discussed again. This paper analyzes the weakness of the blasphemy laws that regulated in Law No. 1/1965 and interpretation of the Constitutional Court on the Law No. 1/1965. The analysis in this paper, by statute approach, conceptual approach, and case approach, shows the weakness of Law No. 1/1965 in putting itself as an entity that is neutral in matters of religion. This weakness caused Law No. 1/1965 set the Government as the interpreter of the religion scriptures that potentially made the state can not neutral. Therefore, the criminalization of blasphemy should be based on criteria without involving the state as an interpreter of the theological doctrine.
\end{abstract}

Keywords: constitutional right, blasphemy, religious interpretation, criminalization, public neutrality

\section{Introduction}

Indonesia is a country with a high level of trust toward religion. This phenomenon is different from majority of the population in European countries. Majority of countries in Europe, because of secularization, tend to leave the religion. The French Revolution was the first trigger for reduction of religious adherents in Europe. Voltaire expressed criticism of religion and affects the distrust of religious institutions. In the field of public administration, there is a separation between state and religion (McGrath, 2006). This situation is different with Indonesia which is the country with great influence of religion in various aspects.

On the other hand, Indonesia is a country that has a history of inter-religious conflict - both between adherents of the same religion and between adherents of different religions. Religious conflicts for a long time and have occurred in Indonesia is the conflict in Maluku. Research on the Maluku conflict after peace shows that the conflict in Maluku is not purely driven by hatred between Muslims and Christians. Economic and political competition is precisely the decisive factor that triggered the conflict (Braithwaite and Dunn, 2010). Furthermore, attacks against Shiites in Sampang (Madura Island) is an example of the conflict between adherents of the same religion in Indonesia. The example shows that Indonesia is a country that has vulnerability to social conflicts related to religion.

The conflict vulnerability could potentially be exploited by third-party for the benefit of any issue that is beneficial both economically and politically. The mode can used to provoke conflict with religious nuance is spreading blasphemy against other religions (or other sects). Development of the internet, especially social media, is an effective and efficient instrument in spreading blasphemy.

The spread of blasphemy can done in various forms. Blasphemy towards other religions can also be done by spreading a negative stigma in a particular religion, or spread negative rumors against the religious activities of certain religious adherents. This means that the scope of blasphemy is very broad and flexible so that it can thrive in any form.

The latest case in Indonesia related to blasphemy involving the Governor of Jakarta (capital of Indonesia), Basuki Tjahaja Purnama. Basuki Tjahaja Purnama was charged with article on blasphemy that has existed since the era of Dutch colonialism. The case politicized by massive demonstrations by mobilizing a large amount of mass.

This paper will check the blasphemy law and public neutrality in the provision. This paper will first check the fallacy 
of blasphemy law in Indonesia in view of public neutrality. After reviewing the fallacy, this paper will discuss judicial review of the blasphemy law and the weaknesses of Constitutional Court's consideration on the decision.

\section{Methodology}

This research is doctrinal legal research. Doctrinal legal research includes the analysis of legal structures, legal framework and case to look for new things with an extensive survey of the literature of law. This research analysis and interpret Law No. 1/1965 and Indonesian Constitutional Court Decision Number 140/PUU-VII/2009. This research also analysis concept of blasphemy in literature of law.

This research uses a variety of approaches that are generally used in doctrinal legal research, namely statutory interpretation, conseptual approach, and case approach. This approach used by the following steps:
a. Identifying relevant facts;
b. Identifying the legal issues;
c. Analysing the legal issues;
d. Analysing secondary sources (textbooks, research reports, journal articles);
e. Analysing primary material (legislation and Constitutional Court decision);
f. Synthesising the legal issues in context;
g. Formulating conclusion.

\section{Results and Discussion}

\subsection{Criminalization of Interpretation in Law No. 1/1965}

Indonesia has Pancasila as philosophical foundation enshrined in the Preamble of the Constitution. With the first principle of Pancasila, Almighty God, puts position of Indonesia in the middle of the mainstream views about the relationship between religion and state. Indonesia is a country that is not a secular state but also at the same time is not a religious state.

Although not a religious country, Indonesia puts divinity and religion in noble place. Preamble of the Constitution (paragraph III) states that independence of Indonesia can not separated from the grace of Allah Almighty. Article 29 paragraph (1) of the Constitution also states clearly that the country based on Almighty God. The formula seemed to justify the state to regulate religion although not a religious state. Claims as a country that is not a secular and not a religious state in fact become doubtful when some legislation at the regional level are likely to enter the religious law into local legislation (Salim, 2008).

State authority to regulate religion in Indonesia can interpreted to prevent religious conflicts. Authority to prevent conflicts without using means restrictions on freedom of the people of a particular religion when the existence of religion potentially lead to conflict with other people. The state actually guarantees freedom of every religious believer, as stipulated in Article 29 paragraph (2) of the Constitution.

On the other hand, the state should not acts as guardian of religious doctrine. That is, the state should not criminalize thoughts or interpretations of religious doctrine except interpretation of religious doctrine directing others to commit criminal acts. In fact, in the context of Indonesia, the state plays an active role to regulate religious doctrine. An example is Law No. 1/1965 on the Prevention of "Religious Abuse and/or Defamation" which is popular as Blasphemy Law (Law No. 1/1965). Law No. 1/1965 passed by President Sukarno to accommodate requests from Islamic organizations to prohibit mystical indigenous beliefs. At that time, politically, mystical indigenous beliefs close to the organizations affiliated to the Communist Party (Crouch, 2012a). Therefore, Law No. 1/1965 was a legal instrument to prevent influence of the Communist Party and harmonize the nationalist and religious group (Adam, 2015).

For decades, Law No. 1/1965 held mere symbolic importance and was rarely enforced. But as religious extremism gained ascendancy in this state, Law No. 1/1965 became a prominent tool to squelch minority in Indonesia. For instance, the Indonesian Government had continued efforts to enforce anti-blasphemy in 2008. This efforts corresponded with a rise in violence against Ahmadi Muslims who are the direct target of those measures (Khan, 2015).

Law No.1/1965 shows place of the state in religious matters more than just support order. Article 1 of Law No.1/1965 states that: "Every one prohibited from deliberately in public conveying, endorsing or attempting to gain public support, any interpretation of any religion adhered to in Indonesia, or from conducting religious activities resembling the religious activities of the said religion, the interpretation and activities of which are deviations from the fundamental teachings of the concerned religion." 
Analysis of Silalahi (2010) concluded that there are at least three important aspects of criminalization in Article 1 of Law No. 1/1965, namely:

a. Requirements of "intentionally acting" and "in public.

The requirements of an intentional act requires that a plan has manifested in concrete actions to make specific goal. Manifestation of intention is not described in this article, but we can see that the action also concluded orally or in writing in this element.

b. The types of prohibited acts.

Two types of conduct prohibited by this Article is the act of interpretation and imitation. Interpretation will normally be included in the scope of the freedom of thought that are non-derogable but this article provides that the interpretation of the act prohibited only if done in public.

c. The core elements of prohibited acts.

This prohibition relates only to the actions or activities of religious interpretations that deviate from the fundamental doctrines of the religion.

The formulation of Article 1 shows that the state forbids all forms of interpretations that deviate from the principal doctrines of the religion. However, to assess whether an interpretation deviate from the principal teachings of religion is not an affair of state (modern), because the assessment is in sphere of theology. State authority to assess whether deviation of religious teachings also do not have logic coherence with Article 29 paragraph (1) and (2) of the Constitution. Although the assessment criteria are deviant theological aspect - which is a matter for theologians - but the state also took over the role as can seen in the Explanation of Article 1 of Law No.1/1965, which states: "The main points of religious doctrine can seen by the Department of Religion that to it have tools/methods to investigate."

Law No.1/1965 provides the threat of criminal sanctions in case of violation of Article 1. The State provides the threat of sanctions that are gradual. The sanctions include:

a. Orders and warnings to stop such actions. The order was given in the form of a joint decision of the Minister of Religious Affairs/Attorney General and Minister of Internal Affairs.

b. If the act committed by an organization or indigenous beliefs, the President may dissolve and ban the organization or the indigenous beliefs.

c. The threat of imprisonment for a most of 5 (five) years if the provisions of Article 1 are still being violated despite the warning, the dissolution and prohibition has done. The criminal penalty threatened to followers, members and/or administrators.

However, whether the order to stop distributing the interpretation, prohibition of organizations, as well as criminal sanctions are proper for differences in religion's interpretation? The differences in interpretation supposed to resolved through a cultural approach (discussion or theological debates) for an understanding of the differences in interpretation. It is difficult to prove that a different interpretation can decline the levels of faith of others. Declining levels faith is an aspect that is not visible and not be measured. The argument that the spread of different interpretations can not used as criteria for measuring the level of faith shown in the case of Hadassah Rev. J. Werner, of Bethel Tabernacle Church in Bandung. Hadassah charged with the interpretation that the "spiritual mother" has a stronger position than the biological mother. On appeal, the Hadassah expressed freely. According to the judge, there are no criteria for measuring the decline of the Christian faith as a result of the Hadassah interpretation (Sihombing et.al, 2012).

Article 4 of Law No. 1/1965 also added one new chapter in the Book of Penal Code - namely Article 156a - so that any person who knowingly publicly issued a feeling or do anything that has the nature of hostility, abuse or desecration of a religion in Indonesia be charged imprisonment up to 5 (five) years. In contrast to Article 1, the Explanation of Article 4 excludes written and oral descriptions that made objectively and scientifically about a religion by avoid words that have the nature of hostility or contempt.

In fact, the existence of Law No. 1/1965 had an impact on the indigenous beliefs. After the September 30 Movement, the Indonesian Communist Party banned by the Indonesian government. At the same time, the PAKEM Team (The Supervision Team of Indigenous Beliefs) intensified their supervision of indigenous beliefs. The indigenous beliefs considered closely related to the Indonesian Communist Party. During the period from 1971 to 1983 , it recorded that the Attorney General's Office banned six indigenous beliefs and sects of Islam and Christian (Silalahi, 2010), namely:

a. Aliran Darul Hadist, Islam Jemaah;

b. Aliran Kepercayaan Manunggal;

c. Agama Budha Jawi Wisnu;

d. Javanese Religious Teachings of Sanyoto;

e. Jehova's Witnesses;

f. Aliran Inkarsunnah. 
This facts show that indigenous beliefs have been the first victim of the blasphemy law with the tendency to protect mainstream religion as regulated in Law No. 1/1965. The government has never considers indigenous beliefs as an equal to the mainstream religions, such as Islam, Protestant, Catholic, Hinduism, and Buddhism. It can seen from the Explanation of Law No. 1/1965 which states that: "The Government shall put in efforts to channel spiritual groups/beliefs towards well-behaved views and towards the Belief in the One and Only God."

Based on analysis of the Law No. 1/1965, conceptually there are three weaknesses of Law No. 1/1965. First, this law does not guarantee any legal action taken by the government on social conflicts caused by blasphemy. Second, the state in this law does not take preventive acts in maintaining order. State actually through Law No. 1/1965 wants be the interpreter of religion. When the state becomes the interpreter, the state will be difficult to take a neutral place in case of conflict (Research Group of Setara Institute, 2011). Third, Law No. 1/1965 has tendency to discriminate the indigenous beliefs.

Based on that weaknesses, Indonesian concept seems inclined to put state as an entity that can influence religion (Hashemi, 2011). Whereas the Constitution (the Preamble and Article 29) does not put religion in Indonesian depending on the state. The model that puts religion depends on the state contribute to failure of the state to prevent social conflicts based on religion. Authority of the state as an "interpreter of the doctrine" has the potential to make the state is not neutral.

Therefore, the state should neutral toward religion by not granting special recognition to certain religions or to religion in general. The public neutrality can prevent the discrimination act to the minority groups, such as indigenous beliefs. The public neutrality toward religion means that the state may not endorse any specific religion or religions. The state also may not promote religion above non-religion or indigenous beliefs in Indonesian context. In other words, public neutrality toward religion forms a wall of separation between religion and state (Kutoroff, 2015). For instance, members of parliament should not vote in favor of a law that establishes Islam as the source of law if they do so with intent of promoting Islamism. Even members of parliament could claim that establishment of Islamism would make civil peace.

\subsection{Judicial review of Law No. 1/1965}

Judicial review of Law No. 1/1965 has done by the Constitutional Court of Indonesia. The petition submitted by the NGO alliance in September 2009 and registered under the case number 140/PUU-VII/2009. They argued that all provisions of this law should declared as unconstitutional and will no longer have any binding force. Their petition based on this arguments:

a. imbalance of Law No. 1/1965 with plurality;

b. the State should neutral in pursuing the fulfillment of its obligation to secure freedom of religion or belief and the State should not take sides with some religions;

c. different interpretation in religion cannot be criminalized;

d. Law No. 1/1965 in fact had created discrimination for indigenous beliefs.

In the Indonesian Constitutional Court Decision (Number 140 / PUU-VII / 2009), the Court rejected the judicial review. The Constitutional Court in its decision stated that interpretation of a doctrine or a particular rule is the freedom to think for everyone. Interpretations can give assurances about something, so that interpretation may lead to the truth and the potential for error. Although interpretation of religious doctrine belief is part of freedom that is at the forum internum, but interpretation must based on the principal doctrines of the religion through the correct method based sources of religion. Therefore, freedom of interpretation in a religion is not absolute. Interpretation with no reference to the method that recognized by religious believers and not based on scriptural sources will cause a reaction that threatens the security and public order when presented or performed in public.

Consideration of the Constitutional Court still raises questions. What is the correct method in interpretation? Does common method recognized by the adherents of the religion is certainly true? The Court has indirectly cut the degree of truth in interpretation religious doctrine. Truth in interpretation religious doctrine considered as pragmatic truth because intersubjectivity and determined by public opinion.

The Court also argued that restriction of the interpretation presented to the public does not violate religious rights. The basic argument of the Constitutional Court is that restrictions on Law No. 1/1965 is an external aspect of freedom (forum externum) where the right to believe in interpretation (forum internum) is not restricted by the state. Forum internum, based on Article 18 of the International Covenant on Civil and Political Rights (ICCPR) includes the right to freely profess and converted as well as the right not forced to adhere a religion or not. The Court refers to Article 18 paragraph (3) ICCPR which states that freedom to manifest one's religion or beliefs may subject only to such limitations as prescribed by law. The limitations are necessary to protect public safety, order, health or morals or the fundamental 
rights and freedoms of others.

If the Court refers to Article 18 of the ICCPR, the Court should give a logical construction that such restrictions are coherent with the Siracusa Principles. Siracusa Principles is the principle of limitation and derogation under the ICCPR. This principle formulated in the meeting of 31 expert panel of human rights and international law in Sicilia in 1984. Panel 31 produces a standard interpretation of the limitation clause in the ICCPR rights. The standard is set that the restrictions do if they meet the relating specific clauses:

a. The restrictions set by law;

b. The restriction necessary in a democratic society;

c. The restriction done to protect the public order;

d. The restriction done to protect public health;

e. The restriction done to protect public morals;

f. The restriction done to protect national security;

g. The restriction done to protect the public safety;

h. The restriction done to protect the rights and freedoms of others;

i. restrictions on public trial.

Based on consideration of the decision, the Constitutional Court emphasised that Article 28J(2) of the Constitution is different from Article 18 of the ICCPR. Article 28J (2) states that: "In the enjoyment of their rights and freedoms, each person obliged to submit to the limits determined by law, with the sole purpose of guaranteeing recognition and respect for the rights of others and to fulfil the requirements of justice and taking into consideration morality, religious values, security, and public order in a democratic community."

Therefore, Article 28J (2) of the Constitution is an explicit and legitimate limitation on the right to religious freedom. The purpose is to protect the rights of the religious majority in the Indonesian context. It based on the 'Pancasila' as the basis of the state as neither secular nor Islamic state. The decision therefore reinforced the legitimacy of state limitations on the right to religious freedom (Crouch, 2012b).

Consideration of the Constitutional Court shows that the Court did not capture violation of constitutional rights by the Law No. 1/1965. Consideration of the Court do not show the analysis of the Act. In fact, the Court has the opportunity to interpret broadly with the principle of judicial activism as had done in a judicial review of other laws. Court should not only analyze Law No. 1/1965 from the viewpoint related restrictions on freedom of expression but also the potential for discrimination against the rights of minorities.

\section{Conclusions}

In the context of Indonesia, the ban on spread of blasphemy should not solely to protect the religion or its adherents. The ban should be positioned as an instrument to make sure order and harmony in life in the community because of spread of blasphemy have the potential to generate conflict. Therefore, state in this context should distant with religion to avoid attention from the state to a certain religion.

Previous discussion in this paper has shown that Law No. 1/1965 is not enough to guarantee preventions of conflict. Law No. 1/1965 have weaknesses in blasphemy formulation which is too wide. The formula debated because it is subjective, based on religious beliefs, so that everyone can assume his actions is not blasphemy. Law No. 1/1965 also regulates criminalization for different interpretation in the religion and set the Government as the interpreter of the religion scriptures. This authority made the state potentially not neutral.

Therefore, the law on blasphemy should reformed. Blasphemy law still needed to prevent social conflict or violences (Rosenfeld, 2003). However, criminalization blasphemy should be based on criteria without involving the state as an interpreter of the theological doctrine. The criminalization blasphemy should also avoid the possible impact on human rights violations to minority groups.

\section{References}

Crouch, M.A. (2012). Law and Religion in Indonesia: The Constitutional Court and Blasphemy Law. Asian Journal of Comparative Law, $7(1), 1-46$.

Crouch, M.A. (2012). Judicial Review and Religious Freedom: The Case of Indonesian Ahmadis. Sydney Law Review, 34(3), 545-572.

Braithwaite, J., Braithwaite, V., Cookson, M., \& Leah, D. (2010). Anomie and Violence: Non-Truth and Reconciliation in Indonesian Peacebuilding. Canberra: ANU E Press.

Haidar, A., (2015). Blasphemy Law in Muslim-majority countries: Religion-State Relationship and Rights Based Approaches in Pakistan, 
Indonesia and Turkey. [Online] Available: http://www.etd.ceu.edu/2015/ adam_haidar.pdf (September 12, 2016).

Hashemi, N. (2011). Islam, Sekularisme, dan Demokrasi Liberal: Menujut Teori Demokrasi dalam Masyarakat Muslim. Jakarta: PT Gramedia Pustaka Utama.

Khan, A.M. (2015). How Anti-Blasphemy Laws Engender Terrorism. Harvard International Law Journal Online, 56, 1-13.

Kutoroff, A. (2015). The First Amendment versus Laícité: Religious Exemptions, Religious Freedom and Public Neutrality. Cornell International Law Journal, 48(1), 247-278.

McGrath, A.E. (2006). The Twilight of Atheism : The Rise and Fall of Disbelief in the Modern World. New York: Doubleday. 2006.

Research Group of Setara Institute. (2011). Menjamin Kebebasan, Mengatur Kehidupan Beragama: Laporan Studi Urgensi Kebutuhan RUU Jaminan Kebebasan Beragama/Berkeyakinan, Jakarta: Pustaka Masyarakat Setara.

Rosenfeld, M. (2003). Hate Speech in Constitutional Jurisprudence: a Comparative Analysis. Cardozo Law Review 24(4), 1523 - 1568.

Salim, A. (2008). Challenging the Secular State: The Islamization of Law in Modern Indonesia. Honolulu: University of Hawai'i Press.

Silalahi, M.R.M. (2010). Protecting The One dnd Only God: A Human Rights Assessment On Indonesian Blasphemy Law (Master's thesis, University of Oslo, Oslo, Norway). [Online] Available: https://www.duo.uio.no/bitstream/handle/10852/22874/1 ThesisxCandidatexNo.x8030.pdf (September 25, 2016).

Sihombing, U. P., P., Aminah, S., \& Roziqin, M. K. (2012). Ketidakadilan dalam Beriman: Hasil Monitoring Kasus-Kasus Penodaan Agama dan Ujaran Kebencian atas Dasar Agama di Indonesia. Jakarta: The Indonesian Legal Resource Center. 